\title{
INFLUENCE OF CROSS-LINE TECHNIQUE TO ABILITY OF MATHEMATICAL REPRESENTATION ON CONTENT MULTIPLICATION OF CLASS III SD AL-ZAHRA INDONESIA
}

\author{
Anis Fuadah Z.1), Fery Muhamad Firdaus'), Zharfa Nur Fajrina ${ }^{3)}$
}

UIN Syarif Hidayatullah Jakarta

Email: anisfuadah.zuhri@uinjkt.ac.id ${ }^{1)}$,fery.firdaus@uinjkt.ac.id²),zharfanurf@gmail.com³)

Naskah diterima : 19 Februari 2019, direvisi : 4 April 2019, disetujui : 15 April 2019

\begin{abstract}
This study aims to determine the effect of cross-line techniques on the ability of the student representation on the material multiplication in Al-Zahra Indonesia Elementary third grade second semester of the academic year 2017/2018. Cross-line technique is one technique that can facilitate students in operating multiplication on learning mathematics. The method used in this research is quasi experiment with Design Nonequivalent Contol Group Design. The sample used in this study consisted of 23 experimental class and control class which consisted of 22 students. The instrument used in this research is a test of mathematical representation ability in the form of description problem. The results showed that the average score of students tanght by using cross-line technique is higher than the students tanght without using cross-line technique that is with the value of 80,57> 70,05. The data analysis of the two classes was calculated using statistical analysis test on the final test (posttest). Based on the result of data analysis, there are significant differences between the two classes which are seen from the test result of Mann-Whitney $U$ test hypothesis on post test data $(0,048<0,05)$. In addition, based on the results of the calculation effect test (effect size) that has been done using the formula Cohen's got the value of the effect size of 0.561 . The value of the influence test obtained interpreted that cross-line techniques have influence in the medium category. Thus, this indicates that there is an influence of the use of techniques that are cross-line to the ability of the mathematical representation in third grade elementary multiplication material of Al-Zabra Indonesia.
\end{abstract}

Keywords: Cross-line Technique, Mathematical Representation Ability, Quasi Experiments.

Pengutipan: Anis Fuadah Z., Fery Muhamad Firdaus, Zharfa Nur Fajrina. (2019). Influence of CrossLine Technique to Ability of Mathematical Representation on Content Multiplication of Class III SD Al-Zabra Indonesia. JMIE: Journal of Madrasah Ibtidaiyah Education,3(1), 2019, 22-31. jmie.v3i1.90.

Permalink/DOI: http://dx.doi.org/ 10.32934/jmie.v3i1.89 



\section{PRELIMINARY}

Mathematics learning has a goal about the ability that must be possessed by students. This ability is better known as mathematical ability. National Council of Teachers of Mathematics/NCTM suggests that "Mathematical ability is the ability to deal with problems, both in mathematics and in real life" (Syafri, 2017). Mathematical ability can be developed by students if students are actively involved in the learning process is not just memorizing information provided by the teacher. Activity of students directly in the process of learning mathematics, will help students to build their own personal and social knowledge in accordance with the theory of learning constructivism. In the theory it is explained that the student can actively build his own knowledge from the knowledge that he has before, becomes a new knowledge that can be easily understood by the student and the teacher only serves as a facilitator who provides facilities or situations conducive to the knowledge construction process undertaken by students can work well.

To be able to develop mathematical skills, students must be able to put their mathematical concepts into various ways or commonly referred to represent. Furthermore, NCTM establishes "The five standards of mathematical ability that students must possess, namely (1) problem-solving skills, (2) communication skills, (3) connection ability, (4) reasoning ability, and (5) representational capabilities" (NCTM, 2000). Accordingly, the ability of representation is considered very important to be developed in students. The development of mathematical abilities aims to enable students to better understand mathematical concepts, to develop and optimize mathematical skills, and to be used as a standard for students' learning ability.

The mathematical representation is the ability of a person to restate the mathematical ideas that have been known before, into other forms such as notation, symbols, images, tables, charts, diagrams, equations, or other mathematical expressions. The usefulness of mathematical representation is to improve and construct mathematical knowledge of students that can help students solve math problems more easily because students are trained to express their mathematical ideas in various forms such as in visual form (images), in mathematical expressions or equations, as well as in words or written text.

Although the ability of mathematical representation is very important in learning mathematics, but in fact this ability is still ruled out by many teachers during the learning process. This is evidenced from the observation that has been done in SD Al-Zahra Indonesia, it was found that in mathematics carried out by teachers in the classroom, teachers pay less attention to and develop students' mathematical representation. This is in accordance with the low ability of students in answering questions relating to the ability of mathematical representation, especially in the material multiplication. Seen from the difficulties students still encounter when asked to restate information data from a multiplication to another representation such as an image corresponding to one's own ideas, describes the problem 
solving of a multiplication problem, establishes the multiplication of a mathematical problem, solves a mathematical problem on the question of multiplication, and making the settlement of a multiplication problem with the words of the idea or idea itself. The cause of this is the lack of teachers in training the ability of mathematical representation of students which resulted in students having difficulty in solving various mathematical problems faced because students are only accustomed to solve a problem in the same way that's all.

Based on these problems, then the way that can be taken to overcome that is with the creativity and innovation of a teacher in learning. Teachers can do learning that can represent conventional ways in ways that use pictures, symbols or notations that can be easily understood by students. One solution that will be done by the researcher to solve the problem in student's mathematical representation is by using cross-line technique in completing the multiplication counting problem.

Cross-line technique is one of the alternative techniques in multiplication concept learning. Through cross-line techniques students can easily understand the concepts of multiplication and can calculate multiplication operations without using memory memories from the memorization of multiplication forms. Because in the use of cross-line techniques, students can represent or represent the methods of memorization and techniques are arranged with lines and dots as symbols in performing multiplication counting operations.

This far, the methods or techniques used in multiplication learning are by the method of memorization for low multiplication and multiplication techniques are structured for multiplication of more than 10 . The method is an easy method, but there are still many students in elementary school / MI who have difficulty in perform calculations with the technique terebut. Due to student-centered techniques are also required to memorize multiplication.

Based on the background of problems that have been described and the advantages contained in cross-line techniques as an effort made in answering the problem of low mathematical representation of students, the authors are interested in conducting research entitled "The Effect of Cross-Line Techniques Using Mathematical Representative Ability in Matter Multiplication Class III SD Al-Zahra Indonesia ".

\section{RESEARCH METHODS}

\section{Research Approach}

The approach taken in this research is quantitative approach. Quantitative approach is used because the purpose of this study is to measure how an action can affect each group.

\section{Research Methods and Design}

The method used in this research is quasi-experiment method. In this method, the researcher selects two or more groups of existing subjects then gives an experimental treatment. This method is selected by researchers because it aims to find the effect of the treatment 
provided. The design in this research uses 'Nonequivalent Control Group Design' design. This study involves two groups, namely the control group and the experimental group. Against both, two different treatments were given. With different treatment in two classes, it can be seen differences that occur in students in the classroom.

\section{Population and Sample}

The population in this study is the third grade students of SD Al-Zahra Indonesia in the even semester of the academic year 2017-2018. The sample in this study was chosen by using purposive sampling technique (Purposive Sample). In this case, sampling is limited to a particular type of person who can provide the desired data, either because they are the only ones who have it, or meet some of the criteria determined by the researcher (Suharso, 2009). This technique is used with the consideration that the selected classes are at the same grade level, the same learning materials and curriculum, and the basic competencies chosen and taught are for class III. So the sample in this study is the third grade students of SD Al-Zahra Indonesia, namely class III-B which is the control class with the number of students 22 people and the experimental class that is class III-A with students who numbered 23 people.

\section{Research Instruments}

The instrument used in this study is a test instrument. The test procedure to be used in this research is pretest and posttest with essay form. In answering the description, the description of how students use their mathematical representation skills will be seen from how students can translate a mathematical problem into visual form, words/language as well as mathematical models/expressions.

The tests used for the control class and the experimental class are the same for measuring the mathematical representation of the students on the multiplication counting material. The instrument is tested first to obtain validity and reliability of the instrument before it is used in the experimental class and control class. Validity test is calculated using Product Moment formula from Pearson with result that item 1b, 1c, 3a, 3b, 3c, 4 have significance level with very significant category and item 1a, 2, 5, 6, and 7 has significance levels with significant categories. Reliability test computed with the Alpha Cornbach formula shows a high reliability instrument results that is equal to 0.88 .

\section{Data analysis}

The analysis done on the data has been obtained to determine the effect of cross-line technique on the ability of mathematical representation on the material of class III SD Al-Zahra Indonesia. The technique used in analyzing the research data is non-parameter inferential statistical techniques. This technique is done by using Mann-Whitney $U$ test on posttest result with significance level 0,05 . Researchers also do effect size test to determine the effect of the data obtained. 


\section{Research Procedure}

The research procedure using quasi-experimental method with nonequivalent control group design is to plan the research by defining the problem to be researched, looking for reference material, determining the research hypothesis, determining the research design, selecting the sample to be studied, and making the learning device and instrument to be used . After that, carry out research that takes precedence by providing pretest to the experimental class and control class. Followed by providing treatment or different treatment in both classes. The experimental class is learning by using cross-line technique on multiplication material while the control class do the learning by using the rote technique and arranged. Furthermore, both classes carry out the final test (posttest) after both are given different treatment with the treatment. The next activity is to analyze the data that has been obtained and make research report.

\section{RESEARCH RESULT}

In this study, researchers used cross-line techniques as another way of determining the results of multiplication counting operations. The cross-line technique in this multiplication is a multiplication counting technique, representing numbers to be counted with lines having the same or different colors and the results of the multiplication are determined by calculating the points that are the point of the meeting or the crossing between the lines. The tools and materials used in making this cross-line technique are stationery (pencils, pens, or colorful markers) and paper. How to create cross-line techniques to be calculated will calculate the result of multiplication $3 \times 5$. The steps taken are:

1. Make 3 horizontal lines tilted around $45^{\circ}$ (like $\lambda$ from the lower left to the top right with not too far away each line (likerli) whose length of line is adjusted to the available space.
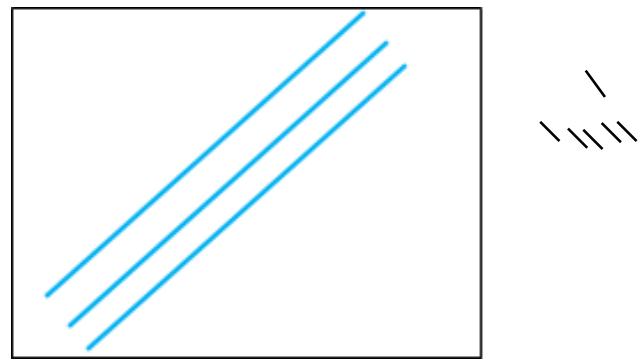

2. Make the 5 perpendicular lines (intersecting with the line representing number 3 ) which is tilted approximately $45^{\circ}$ (like ) from the top left to the bottom right with not too far away each line (like ) the length of the line is adjusted to the available space. 


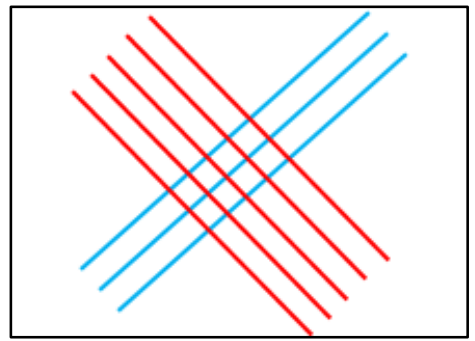

3. Calculates the crossing points between the lines.
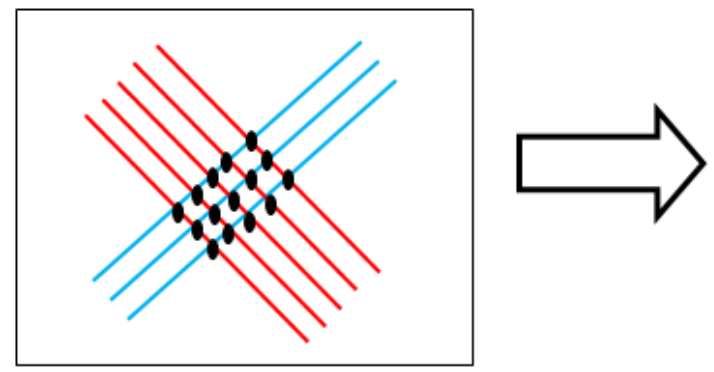

The points in the crossed line there are 15 points. So, it can be seen

that the result of $3 \times 5=15$

This cross-line technique has advantages in its use, among others: 1) can be used anytime, anywhere, and for anyone, 2) attract student interest because there are elements of drawing lines and dots with colors, simple and easy, 3) students do not need to memorize in completing multiplication calculations, even in basic multiplication though, and 4) this technique uses visual means in the process, so it can be easily seen and understood by students (Arisandi, 2014).

Cross-line techniques are used by researchers as one way that can improve students' mathematical representation. Through cross-line techniques, students are trained in the ability to express or represent a thing into another form. Previously it was known that students in grade III SD Al-Zahra Indonesia had low mathematical representation ability through pretest result which showed average of 60.20 in experiment class and 60.32 in control class.

After the implementation of different treatments by implementing the learning with cross-line techniques in the experimental class and rote technique and in the control class, the activity in the next research is to conduct the final test (posttest) in the two classes that get the average value of 80.57 in the experimental class and 70.05 in the control class. The results obtained from the pretest-t test of student's mathematical representation indicate that the significance value of $0.986>0.05$ then $\mathrm{H}_{0}$ is accepted. It can be said that there is no significant difference between the mean pretest of the experimental class and the control class. While the result of Mann-Whitney test $u$ the mean value of posttest of student's mathematical representation ability show significance value $0.048<0.05$ then $\mathrm{H}_{0}$ is rejected. So it can be concluded that there is a difference between the average post test result of the experimental class and the control class. 
After conducting hypothesis test on the average of pretest and posttest value of students' mathematical representation ability, the researcher then conducted a big test of influence to find out how much influence obtained from the use of cross-line technique to the ability of mathematical representation on the material of class III SD Al-Zahra Indonesia. The results obtained from the calculation of effect size by using Cohen's formula is 0.561 and included in the degree of influence of the category being interpreted by classification according to Cohen's. So it can be concluded that the use of cross-line technique gives a significant influence on the ability of mathematical representation on the material of class III of SD AlZahra Indonesia.

\section{DISCUSSION}

The result of the average posttest in the experimental class 80.57 , while the control class only 70.05. The data shows that the use of cross-line techniques has an effect on the increased ability of students' mathematical representation. In accordance with the opinion of Turner (2013), that representation is the basis for understanding mathematics because it is used to organize, record and communicate mathematical ideas as well as to translate ideas in solving problems and interpreting mathematics. So if students continue to be trained in the ability of mathematical representation with various ways/techniques that vary, students will be easier in understanding the concepts of mathematics.

The use of cross-line techniques that can improve students' mathematical representation abilities due to cross-line techniques is one way that can translate a multiplication form into lines and dots. It agrees with Misel and Erna Suwangsih that the ability of mathematical representation is the ability of a person to present a mathematical idea that includes translation of problems or mathematical ideas into interpretations in the form of images, mathematical equations, and words (Misel and Suwangsih, 2016 ).

The influence of cross-line use on improving mathematical representation in this study, in line with Piaget's opinion, argues that the development of MI/SD children aged 7 to 11 years is in the concrete operational phase. Which means that MI/SD students can reason logically, but still relate to concrete real objects that can be captured by the five senses (Wafiqni and Latip, 2015). Thus, cross-line technique is an appropriate technique to be used as an alternative in multiplication mathematics learning because the lines and dots on cross-line techniques are real objects that can facilitate students in calculating multiplications so that students can easily calculate the results of multiplication by representing the numbers that will be multiplied by the lines and calculating the points of the meeting.

The use of cross-line techniques can be used as an alternative in training students' mathematical representation skills because in learning mathematics, students are required to learn abstract concepts. This is in accordance with the opinion of Bruner who explained that learning mathematics is to learn about the concepts and abstract structures contained in 
mathematics as well as looking for relationships between concepts and mathematical structures (Widayati, et al, 2009). Therefore in this study, researchers used cross-line as a tool that can be easily captured by the senses of students in learning abstract concepts such as multiplication.

As long as the researcher conducts the learning in the experimental class, the researcher observes that the use of cross-line techniques in multiplication materials can make students active in learning. That's because the use of cross-line can attract students' interest because there are elements of drawing lines and dots with colors, simple and easy (not complicated). In the discussion while working on the LKS, the students discussed actively and worked on the problem together. Students also do not need to memorize in completing multiplication calculations, even in basic multiplication though. It has a positive effect on the learning objectives to be achieved. In contrast to the learning done in the control class. Students tend to not actively discuss and some students are eager to work individually. The results of this observation, in accordance with Hurlock's opinion that there are factors that affect the development of learners, such as ontogenik is an external function that develops from the learning process, exercises, experiences, and others such as writing, reading and counting (Wafiqni and Latip, 2015). So in the learning that is done, should provide exercise and experience that is fun and tailored to the characteristics of learners who can develop skills such as learning with cross-line techniques that can develop the learning process of students become more meaningful.

The difference between the average post test score of the students in the experimental class and the control class in this study is due to the experience gained by the two different classes. The experimental class gets learning using cross-line techniques, while the control class does a fixed learning by using rote and composite techniques. The results of this study are in accordance with the opinion of Slameto, which explains that learning is a process of business undertaken by individuals to obtain a whole new behavioral change, as a result of individual experience itself in interaction with the environment (Djamarah, 2002).

The explanation of the results of this study, in accordance with previous studies that have been done on cros-line techniques on multiplication and also the ability of students' mathematical representation, such as research conducted by Wahyu Amrullah with his research entitled "The Effect of Tipot Method (Spot Cut) in Increasing Understanding of Grade IV Students of SDN 2 Paniis and SDN 1 Paniis Kecamatan Pasawahan of Kuningan Regency ". The results showed that there are differences in pretest and posttest average in the experimental class. So $\mathrm{H} 0$ is rejected or $\mathrm{H} 1$ accepted. So it can be concluded that the method Tipot can improve students' understanding of class IV in the material multiplication significantly.

Desy Iswara with his research entitled "The Influence of the Use of Frame Wheeler Tools to Student Mathematical Representation Ability". Based on the results of research that has been carried out, shows that there is influence of the use of propagation wheel tool to the ability of students' mathematical representation in the fourth grade of Islamic elementary school 
Al-Fakhiriyah. This is shown from the result of posttest average value indicates that experiment class is higher than control class that is equal to 81.04 for experiment class and control class equal to 70.80 .

\section{CONCLUSION}

Based on the results of the processing of research data that has been done, it can be concluded that the use of cross-line techniques have an influence on the ability of mathematical representation on the material of class III SD Al-Zahra Indonesia. This has been proven from the results of the hypothesis test calculation on the average value of the final test (posttest) students experimental class that is equal to 80.57 and the control class of 70.05 . The result of hypothesis test on the mean value of posttest with significance level 0.05 fulfilled criteria of significance $<0.05$ that is $0.048<0.05$. The result of hypothesis testing (Mann-Whitney $\mathrm{U}$ test) shows that based on predetermined criteria, the null hypothesis $\left(\mathrm{H}_{0}\right)$ is rejected and hypothesis one $\left(\mathrm{H}_{1}\right)$ is accepted. So it can be concluded that there is an influence in the use of cross-line techniques on the ability of mathematical representation in class III multiplication material.

The use of cross-line techniques in the learning process in this multiplication material gives effect in the medium category to the students' mathematical representation. This is evident from the result of the calculation of effect test by using Cohen's calculation formula, which gets the effect size (d) value of 0.561 which is interpreted into the moderate level of influence category. So it can be concluded that there is a significant influence in the use of cross-line techniques on the ability of mathematical representation in class III multiplication material.

Based on the research results, it is known that the implications of the research results are to improve the ability of mathematical representation, students can be trained by using crossline techniques in calculating the multiplication that can make students motivated during active learning. In addition, teachers can be more motivated in training students' mathematical representation abilities with various techniques or appropriate ways to be used in the learning process. The results of this research have shown that the use of cross-line techniques has a good influence on the ability of mathematical representation in class III multiplication material, so cross-line technique can be used as an alternative in mathematics learning especially in multiplication material.

\section{BIBLIOGRAPHY}

Arisandi, Elisa. Meningkatkan Kemampuan Operasi Perkalian untuk Anak Diskalkulia Melalui Metode Garismatika. Jurnal Ilmiah Pendidikan Khusus vol. 3, 2014.

Djamarah, Syaiful Bahri. Psikologi Belajar. Jakarta: PT. Rineka Cipta, 2002. 
Misel dan Erna Suwangsih. "Penerapan Pendekatan Matematika Realistik Untuk Meningkatkan Kemampuan Representasi Matematis Siswa". Universitas Pendidikan Indonesia, Metodi Didaktik Vol. 10, No. 2, 2016.

NCTM. Principles and Standars for School Mathematics. United States of America: The National Council of Teachers of Mathematics, Inc., 2000.

Suharso, Puguh. Metode Penelitian Kuantitatif: Untuk Bisnis. Jakarta: PT. Indeks, 2009.

Syafri, Fatrima Santri. Kemampuan Representasi Matematis Dan Kemampuan Pembuktian Matematika. Jurnal Edumath. Volume 3 No. 1, 2017.

Turner, Silvya. Teachin Primary Mathematics. India: Replika Press, 2013.

Wafiqni, Nafia dan Asep Ediana Latip. Psikologi Perkembangan Anak Usia MI/SD. Jakarta: UIN PRESS, 2015.

Widayati, Esti Yuli dkk. Pembelajaran Matematika MI LAPIS PGMI. Surabaya: Aprinta, 2009. 